\title{
Kilit denetim konularının Uluslararası Denetim Standardı (UDS) 701 kapsamında incelenmesi
}

\author{
Doç.Dr.Duygu CELAYía ${ }^{a}$, Prof.Dr. Hasan TÜREDi ${ }^{b}$
}

a*istanbul Ticaret Üniversitesi, İşletme Fakültesi, Muhasebe ve Denetim Bölümü, e posta: dcelayir@ticaret.edu.tr, Orcid: 0000-0002-1435-3910 b*istanbul Ticaret Üniversitesi, İşletme Fakültesi, Muhasebe ve Denetim Bölümü, e posta: hturedi@ticaret.edu.tr, Orcid: 0000-0001-6817-0717

\author{
MAKALE BíLGILERI \\ Araştırma Makalesi \\ Geliş Tarihi 2 Mayıs 2021 \\ Revizyon 23 Mayıs 2021 \\ Revizyon 30 Mayıs 2021 \\ Revizyon 4 Temmuz 2021 \\ Revizyon 3 Ekim 2021 \\ Kabul tarihi 15 Kasım \\ 2021
}

\begin{abstract}
Özet
Bugünün değişen iş ortamı, mali işlemlerin karmaşıklığı ve beraberinde yaşanan muhasebe/denetim hileleri, kaliteli ve güvenilir mali raporlamanın önemini artırmıştır. Mali tabloların güvenilirliği, özellikle ABD'de ortaya çıkan Enron ve sonrasında Tyco, WorldCom, gibi şirket muhasebe ve denetim hileleri ile birlikte sorgulanır hale gelmiştir. Aynı zamanda mevcut durum ve olaylar, mali raporlamanın kalitesini destekleyen süreçler hakkında daha fazla bilgi talebini ortaya çıkarmış ve bilgi kullanıcılarının, denetime şeffaflık sağlayan denetim raporu ihtiyacını görünür duruma getirmiştir. Yaşanan gelişmeler sonucunda, dünya genelinde sermaye piyasaları mevzuatı ile muhasebe ve denetim standartlarının yeniden gözden geçirilmesini içeren bir düzenleme süreci başlamıştır. ABD'de Sarbanes-Oxley Yasasının (SOX) çıkarılmasıyla birlikte, diğer ülkelerde de buna uyumlu mevzuat düzenlemeleri yapılmıştır. Bu süreçte, bağımsız denetime olan güvenin yeniden oluşturulabilmesi ve denetimde şeffaflık ile denetim raporlarının ihtiyaca uygunluğunun artırılması amacıyla, uluslararası denetim standartlarının gözden geçirilmesi ve ilave standartların çıkarılması çalışmaları başlamıştır. Mali tablo kullanıcılarının taleplerini karşılamaya yönelik olarak yürütülen çalışmalar neticesinde, güncellenmiş denetim standartları IAASB tarafından 2016 yılından itibaren uygulanmak üzere yürürlüğe konulmuştur. Denetim raporlamasının geliştirilmesi amacıyla yapılan yeniliklerin en önemlilerinden biri Uluslararası Denetim Standardı (UDS) 701 "Kilit Denetim Konularının Bağımsız Denetçi Raporunda Bildirilmesi Standardı" dır. Bu standart, denetçi raporunun iletişim değerinin arttırılması, raporda şeffaflığın artırılarak denetim süreci hakkında kullanıcılara daha fazla bilgi sunulması amacıyla yürürlüğe konulmuştur. Bu çalışmada, kilit denetim konularının ne olduğu, bunların denetçi tarafından nasıl belirleneceği ve denetim raporunda nasıl bildirileceği açıklanmış ve UDS 701 kapsamında incelenmiştir. Aynı zamanda kilit denetim konularının şeffaflığı artırmaya yönelik etkileri de yine standart kapsamında belirtilmiştir.
\end{abstract}

Anahtar Kelimeler: Bağımsız Denetim, Denetim raporu, UDS 701

Key audit issues and a study within the scope of the International Audit Standard (IAS) 701

\section{ARTICLE INFO}

Research Article Received 2 May 2021 Received in revised form 23 May 2021 Received in revised form 30 May 2021 Received in revised form 4 July 2021 Received in revised form 3 October 2021 Accepted 15 November 2021

\begin{abstract}
Today's changing business environment, complexity of financial transactions and the accompanying failures in auditing processes have created a requirement to emphasize on high quality and reliable financial reporting. Reliability of financial statements has been questioned, especially after the Enron scandal in the USA and the subsequent Tyco, WorldCom scandals. In the meanwhile, as the result of these cases and the emerged situation, users of information have started to request more information on the processes supporting the quality of financial reporting. This has led to the concept of transparent audit reports. As the result of a number of developments, a regulation process has been initiated globally, which has included the review of capital markets regulations, and accounting and auditing standards. Some of the objectives of this era have been to reinstate the trust in independent audit, to increase transparency of auditing activities, and to increase the capability of audit reports to meet the requirements. To reach these objectives, international auditing standards have started to be reviewed, and additional standards have been brought forward. As the result of the activities carried out to meet the requests of users of financial statements, updated auditing standards were put into force by IAASB, to be applicable as of 2016. One of the major novelties in developing the audit reports has been the International Standard on Auditing (ISA) 701, "Communicating Key Audit Issues in the Independent Auditor's Report". The standard was launched with the purpose of increasing the communicative value of the audit reports, and providing more information to the users on the audit process by way of making the reports more transparent. This study examines what the key audit issues are, how these will be specified by the auditors, and how these will be included in the audit reports, within the scope of ISA 701. Also, the study evaluates the impact of key audit issues on increasing transparency, also within the scope of the standard.
\end{abstract}

Keywords: Independent Audit, Audit Report, ISA 701

\section{Giriş}

Son 20 yılda yaşanan Enron, Worldcom, Xerox, Parmalat v.b. muhasebe ve denetim hileleri, mali raporlamanın güvenilirliğinin sorgulanmasına neden olmuştur. Ortaya çıkan hileli mali raporlar, kaliteli ve etkin bağımsız denetimin gerekliliğini ortaya çıkarmıştır.

Bağımsız denetimin amacı; mali tabloların, uygulanabilir mali raporlama çerçevesi doğrultusunda bir işletmenin mali durumunu ve faaliyet sonuçlarını tüm önemli yönleriyle gerçeğe uygun ve doğru bir biçimde gösterip göstermediği konusunda bağımsız denetçinin görüş bildirmesini sağlamaktır. Bu bağlamda bağımsız denetim; mali tablolara güvenilirlik sağlayarak iktisadi ilişkilerin, sermaye piyasalarının ve işletme faaliyetlerinin etkinliğini ve verimliliğini arttıran önemli bir role sahiptir. Bağımsız denetim yaklaşımındaki temel düşünce; işletme dışındaki bilgi kullanıcılarının; mali tabloların güvenilirliğine ilişkin algılarını güçlendirmek ve arttırmaktır (Schuetze, 1994). Bağımsız denetimin önemli bir işlevi üstlenmesine rağmen, yaşanan şirket muhasebe ve denetim hileleri, gerek bağımsız denetim gerekse mali raporlamayla ilgili yapılan düzenlemelerin yeterli olmadığını göstermiştir.

Bu bağlamda bilgi kullanıcıları, denetimde şeffaflığı artıracak düzenlemeleri ve denetçi raporlarının kapsamının genişletilmesini talep etmişlerdir. Bu talepler neticesinde, son yıllarda denetçi raporlama şeklinde önemli değişimler ortaya çıkmıştır. Bu gelişmelerden biri, denetçinin, denetim sırasında dikkat gösterdiği konulardan en çok önem arz edenleri olarak tanımlanan kilit denetim konularını, denetim raporunda bildirmesidir (Gold \& Heilmann, 2019).

Kilit denetim konuları, denetçinin mesleki muhakemesine göre, cari döneme ait mali tabloların denetiminde en çok önem arz eden konulardır (BDS 701, pr.8). Bu konular, bir bütün olarak mali tablolara ilişkin olarak uygulanan denetim çerçevesinde ve bu tablolara ilişkin görüş oluşturulurken ele alınmaktadır. Başka bir ifade ile Kilit denetim konuları, mali tabloların denetiminde karşılaşılan en önemli risklerdir. Örneğin, işletmenin sürekliliğinin değerlendirilmesi, kontrol eksiklikleri, stokların değerlemesi gibi konular kilit denetim konularına örnek olarak verilebilir. Bir denetim çalışmasında, genel strateji ve kaynakların tahsisi üzerinde büyük etkiye sahiptirler. Kilit denetim konuları, denetçiler tarafından raporlarında gösterilir. Kilit denetim konularının raporlanması, daha şeffaf 
ve anlamlı denetimlerin yolunu açmakta ve kullanıcılara büyük ölçüde fayda sağlamaktadır. Kilit denetim konularının denetçi raporunda bildirilmesiyle, denetçi raporunun şeffaflığı ve bilgi düzeyinin arttııılması amaçlanmaktadır. Denetim raporlamasındaki ana değişiklikler, bilgi boşluğunu/farkııı̆ı̆ıı azaltmayı amaçlamaktadır. Uluslararası Denetim ve Güvence Standartları Kurulu (IAASB), bu boşluğu, bilgi kullanıcısının arzusu ile işletmenin açıklamaları ve denetçinin raporunda kendisine ne sağladığı arasındaki fark olarak tanımlamıştır (Segal, 2017).

\section{Denetim Raporlarının Genişletilmesi intiyacı}

Denetim raporu denetim sürecinin son çıktısıdır. Denetçiler görüşlerini denetim raporunda ifade etmektedirler. Bağımsız denetimde, denetim raporu; yönetim tarafından hazırlanan muhasebe bilgilerinin, bir bütün olarak geçerli mali raporlama çerçevesine göre hazırlanıp hazırlanmadığı ile ilgilidir (IAASB, 2013). Bilgi kullanıcıları denetçi raporunu her zaman önemli bir bilgi kaynağı olarak görmüşlerdir. Gomez ve Guillamon’a (2003) göre denetim raporları, yönetim tarafından hazırlanan mali bilgilere değer katmaktadır. Literatürde yapılan çalışmalar, denetim raporlarında kilit denetim konularının açıklanmasının, hem denetim hem de mali raporlama kalitesini artırdığına işaret etmektedir. Çalışmalar, kilit denetim konusu açıklamalarının şeffaflığı artırarak, mali raporlama kalitesi üzerinde olumlu bir etkiye sahip olduğu ve daha az agresif mali raporlama davranışına ve dolayısıyla raporlama kalitesinde artışa yol açacağını ortaya koymuştur (Bédard, Gonthier-Besacier, \& Schatt, 2018; Boolaky \& Quick, 2016, Lennox, Schmidt, \& Thompson, 2019).

Bilgi kullanıcılarının bakış açısına göre denetçi raporları; kesin olmamakla birlikte, yönetimin sunumları hakkında makul güvence sağlayan bir unsur olarak görülmektedir. Denetçinin bakış açısına göre denetim raporları; işletme paydaşlarıyla iletişimin önemli bir aracıdır. Ancak denetim standartları, denetim raporlarında bulunması gereken bilgi ve şeklinin en üst sınırını değil en az bilgiyi sunmaktadır. Ayrıca denetçi raporu, denetlenen şirketle iletişimin de önemli bir aracıdır. Doğrudan yönetime rapor vermekten ziyade iletişim, şirket içindeki bağımsız bir izleme kümesi olarak denetim komitesi üzerinden yürütülmektedir. UDS 260’a göre, şirket yönetimiyle ilgili önemli hususların, denetçiler tarafından denetim komitesine (varsa) veya yönetim kuruluna bildirilmesini gerektirmektedir. Bu yönüyle denetçi açısından iletişimin iki yönü bulunmaktadır.

Başta yatırımcılar olmak üzere işletme paydaşları, denetim raporunda daha fazla bilgi görmek istemektedir. Ancak denetçiler gizlilik kaygılarıyla kısıtlanmış, aynı zamanda ne söylediklerini ve nasıl söylediklerini ortaya çıkaran bir dava tehdidiyle de sınırlandırılmışlardır (Gray\&Manson, 2000). Bu bağlamda denetçi raporundan beklentilere ilişkin hususların, bilginin içeriğine ve raporun sunuluş şekline yoğunlaştığı görülmüştür. Denetçi raporu, denetçiler ile mali tablo kullanıcıları arasındaki iletişimin en temel aracıdır (PCAOB, 2017). Ancak, geleneksel raporlama şekli oldukça standartlaştırıldığından, yararlı bilgiyi sunum ve şeffaflık açısından yetersiz kalmıştır (Asare \& Wright 2012; IAASB, 2011). Özellikle, 2000'li yıların başında ortaya çıkan mali sorunları ile 2008 mali sorununun hemen ardından, kanun koyucular, standart belirleyiciler ve yatırımcılar, denetçi raporunun bilgilendirici değerini ciddi bir şekilde sorgulamaya başlamıştır. Benzer şekilde, son on yılda yapılan bilimsel araştırmalar da, sürekli olarak, denetim raporu yeniliklerini destekleyici bir yaklaşımla, raporlarda değişime ihtiyaç olabileceğini vurgulamışlardır (Carcello, 2012; Turner etc. 2010). Mock ve diğ. (2013), işletme paydaşlarının; denetim süreci, denetçi ve mali tablolar hakkında daha fazla bilgi istediği sonucuna varmıştır. Vanstraelen ve diğ. (2012), bilgi kullanıcılarının önemli risk alanları gibi denetim bulgularıyla ilgili ek açıklamalar ile ilgilendiklerini tespit etmişlerdir. Bu kapsamda denetçi raporunun geliştirilmesi, hem denetimin toplum tarafından algılanan değerini, hem de bağımsız denetim mesleğinin geçerliliğini sürdürebilmesi açısından önem kazanmıştır.

Genel olarak, yapılan araştırmalar, bilgi kullanıcılarının hazırlanan mali tablolar ve gerçekleştirilen denetimden bekledikleri/arzu ettikleri bilgiler ile bir şirketin denetlenmiş mali tablolarında ve denetim raporunda bulunan bilgiler arasında bir farklılık olduğunu göstermektedir. Standart koyucular ve çeşitli araştırmacılar bu durumu "bilgi boşluğu" olarak açıklamaktadır (IAASB 2012; Gold\&Heilmann, 2019; Mock v.d.. 2013). Bilgi farklılığı/ boşluğu, bilgi kullanıcılarının bir denetimden beklentileri ile bir denetimin gerçekte ne olduğu arasındaki farkı tanımlayan uzun süredir devam eden beklenti boşluğu ile de yakından ilgilidir (IAASB 2011). Bu tartışmalar ve yapılan araştırmalar, denetçi raporunun iletişim açısından değerini artırmak için dünya genelinde birçok girişimin ve düzenlemenin yapılmasına neden olmuştur. International Auditing and Assurance Standards Board - IAASB (Uluslararası Denetim ve Güvence Standartları Kurulu), European Commission- EC (Avrupa Komisyonu), Public Company Accounting Oversight Board - PCAOB (Halka Açık Şirketler Muhasebe Gözetim Kurulu) ve İngiltere Mali Raporlama Konseyi (FRC) denetçi raporunu geliştirmek için çeşitli girişimler yapmışlardır. Bu düzenlemeler arasında en öne çıkan ise IAASB tarafından denetim standartlarında yapılan değişiklikler ve yeni denetim standartlarıdır.

\section{“Kilit Denetim Konuları” ve Yapılan Düzenlemeler/UDS 701}

Mali tablo kullanıcılarının bilgi ihtiyacının artması ile birlikte, denetçi raporunu iyileştirmenin olası yollarını aramak ve devam eden beklenti ve bilgi boşluğuyla ilgili olarak çözüm yolu bulmak için Mayıs 2011'de, IAASB “Denetçi Raporlarının Değerinin Arttırılması: Değişim Seçeneklerini Araştırmak" konulu istişare raporunu yayınlamış ve standartlarda gerekli değişikliklerin yapılmasıyla ilgili bir proje başlatmıştır (IAASB 2011). IAASB'in daveti ve önerdiği değişiklikler, çeşitli paydaşlar tarafından yüksek düzeyde destek görmüştür (Prasad \& Chand 2017). Temmuz 2013'te, devam eden bu girişimleri, “Denetimden Geçmiş Mali Tablolara İlişkin Raporlama: Önerilen Uluslararası Denetim Standartları" taslak raporu takip etmiştir. Ocak 2015'te IAASB, denetçinin raporunda kilit denetim konularının açıklanması gerekliliği de dahil olmak üzere yeni ve düzeltilmiş denetim standartlarının son şeklini yayınlamasıyla, söz konusu çalışmayı tamamlamıştır (IAASB, 2015).

IAASB tarafından denetim standartlarında yapılan düzenlemeler sonrası denetçi raporunda yapılan en önemli değişiklikler; kilit denetim konularının denetçi raporlarında yer alması, denetim raporunda yer alan bilgilerin sırasının değişmesi, denetçinin ve yönetimin sorumluluğu ile ilgili açıklamaların kapsamına işletmelerin sürekliliği ile ilgili açıklamaların eklenmesi, denetçinin bağımsızlığına ve ahlaki ilkelere uyum ile ilgili açıklamaları olarak sıralanabilir. UDS 700 “Mali Tablolara İlişkin Görüş Oluşturma ve Raporlama” Standardı ile denetim çalışması sonucunda denetçinin görüşünü sunduğu denetçi raporunda şekil ve içerik anlamında önemli değişiklikler yapılmıştır. Ayrıca, UDS 260 "Üst Yönetimden Sorumlu Olanlarla Kurulacak İletişim Standardı", UDS 570 "Işletmenin Sürekliliği Standardı”, UDS 705 “Bağımsız Denetçi Raporunda Olumlu Görüş Dışında Bir Görüş Verilmesi Standardı”, UDS 706 “Bağımsız Denetçi Raporunda Yer Alan Dikkat Çekilen Hususlar ve Diğer Hususlar Standardı" gibi standartlarda da düzenlemeye gidilmiştir. Önemli bir gelişme de, "Kilit Denetim Konularının (KAM) Bağımsız Denetçi Raporunda Bildirilmesi” başlıklı standart (UDS 701) olmuştur.

Kilit denetim konularının raporlanması, son yıllarda denetçi raporlamasındaki en önemli gelişmelerden biri olmuştur. Denetim raporlarının mali tablo kullanıcılarına, denetim faaliyetinin yürütülmesiyle ilgili olarak ayrıntılı bilgi sunması gerektiği düşüncesiyle, denetçinin raporunda denetim faaliyetini yürütürken en önemli gördüğü konuları (kilit denetim konuları) ve bu konuların denetimine ilişkin izlediği yolu bildirmesi amaçlanmıştır. Bu amaçla “UDS 701 Kilit Denetim Konularının Denetçi Raporunda Bildirilmesi” standardı IAASB tarafından yayımlamıştır. UDS 701, Uluslararası Denetim ve Güvence Standartları Kurulu (IAASB) tarafından Ocak 2015'te yayınlanmış ve 15 Aralık 2016 tarihinde veya bu tarihten sonra sona eren hesap dönemlerine ait mali tabloların denetimleri için geçerli kılınmıştır. Genel hedefi, denetçi raporunun değerini ve ilgi düzeyini arttırmak olan UDS 701, cari yılın denetiminde, denetçinin mesleki yargısında en önemli olan konular olarak öne çıkan kilit denetim konularını tanımlamaktadır. Kilit denetim konularının bildirilmesinin amacı, yürütülen denetime ilişkin daha fazla şeffaflık sağlayarak denetçi raporunun iletişim değerinin artırılmasıdır (UDS 701, par 2-3).

Kilit denetim konularının bildirilmesi; mali tablo kullanıcılarının işletmeyi ve denetlenen mali tablolardaki önemli alanları anlamalarına katkı sağlayacak, böylelikle kullanıcıların, yönetim ve üst yönetimden sorumlu olanlarla daha şeffaf ve etkin iletişim kurmalarını kolaylaştıracaktır. Bu düzenleme aynı zamanda, denetçi raporunda hangi konularda iletişim kuracağına ve bu iletişimin biçim ve içeriğine ilişkin denetçinin kararına ışık tutmaya yardımcı olacaktır. Sonuç olarak, güncellenen raporlama standartları denetçinin performansından kaynaklanan hem beklenti hem de iletişim farkını da azaltmaya imkan sağlayacaktır (Nwaobia v.d., 2016). Bu bağlamda, denetim raporu standardında yapılan değişiklikler, denetim standartlarına uygun olarak yapılan bir denetimin şeklini, kapsamını ve içeriğini değiştirmemekte, ancak, genişletmektedir.

\section{Kilit Denetim Konularının Belirlenmesi}

UDS 701, kilit denetim konularını "cari dönemin mali tablolarının denetiminde, denetçinin mesleki kararında en önemli olan hususlar" olarak tanımlamaktadır (IAASB, 2015). Ayrıca, ilgili standartta, kilit denetim konularının yönetimden sorumlu olanlara iletilen konulardan seçildiği belirtilmektedir. 
Standart, "denetim sırasında, denetçi dikkatini gerektiren önemli konuları" açıklarken (IAASB, 2015), önemli risk alanlarının yanı sıra mesleki muhakemenin kullanılması gereken alanları da içermektedir (Simpson \& Weiner, 1989).

Doğan (2018) tarafından yapılan çalışmada, denetçi raporlarının, mali tablo kullanıcılarına denetim ve denetim süreçleri hakkında önemli bilgilerin iletilmesi açısından etkin olmadığı ve son yıllarda denetçi raporunun daha fazla bilgi vermesi, özellikle de denetçilerin, yaptıkları denetim sonucunda kullanıcılara daha fazla yararlı ve şeffaf bilgi sağlamaları konusunda başta kurumsal yatıımcılar olmak üzere, finansal tablo kullanıcılarından talepler geldiğinden bahsetmiştir. Bu doğrultuda denetçi raporlarının genişletilmesi konusunda UDS 701 önemli bir gelişme olarak ortaya çıkmıştır.

Denetçi kilit denetim konularını seçerken üst yönetimden sorumlu olanlara bildirilen konuları öncelikle incelemelidir. Bu konuları önemlilik düzeyine göre önceliklendirmeli ve konuların içerdiği riskleri, risklerin önemlilik düzeylerini dikkate almalıdır (UDS 701, md.9). Buna göre denetçi, aşağıdaki durumlarla birlikte denetim sırasında yoğunlaştığı alanları dikkate almalıdır

Bunlar (Uzay ve Köylü, 2018);

Önemli yanlışlık riski içeren veya önemli denetçi yargısı içeren alanlar,

Denetçinin yeterli uygun denetim kanıtı elde etmekte dâhil olmak üzere denetim sırasında önemli zorluklarla karşılaştı̆ıı alanlar,

İç denetime ilişkin önemli bir eksikliğin tespit edilmesi de dâhil olmak üzere denetçinin planlanan denetim yaklaşımında önemli bir değişiklik gerektiren alanlardır.

Kavut ve Güngör (2018) yaptıkları incelemede, BIST 100 şirketlerinin 2017 yılı bağımsız denetim raporlarının kilit denetim konuları kısmına içerik analizı uygulamışlardır. Yaptıkları çalışma sonucunda, BiST 100 şirketlerinde en çok raporlanan kilit denetim konuları şerefiye, hasılat ve ticari alacaklar olarak tespit edilmiştir.

Gökgöz (2018) yaptığı araştırmada Borsa'da işlem gören 140 şirketin 2017 yılındaki bağımsız denetim raporlarının kilit denetim konuları kısmına içerik analizi uygulamışıิır. Yapılan içerik analizi sonuçlarına göre, en çok raporlanan kilit denetim konularının sırayla; hasılat, ticari alacaklar, stoklar, maddi duran varlıklar ve yatırım amaçlı gayrimenkuller ile ilgili olduğu sonucuna ulaşmıştır.

Kilit denetim konularının tespitinde önemli yönetim değerlendirmelerini, muhasebe tahminlerini, cari denetimde ortaya çıkan önemli olaylara ilişkin işlemleri değerlendiren denetçi, denetim faaliyetinin yürütülmesi sırasında yüksek derecede dikkat gerektiren konuları belirlemelidir. Belirlenen bu konular arasından seçilen ve denetçinin mesleki yargısına göre denetimde en çok önem gerektiren konular denetim raporunda kilit denetim konusu olarak bildirilmektedir.

Bu kapsamda, denetçi, kilit denetim konularını belirlemeden önce başlangıçta, üst yönetimden sorumlu olanlara bildirdiği konular arasından, denetim sırasında en üst düzeyde (en çok) odaklandığı konuları belirlemelidir.

Denetçi bu konuları belirlerken aşağıdaki hususları her zaman dikkate almalıdır (KGK, 2016).

- Değerlendirilmiş önemli yanlışlık riskleri veya önemli risklerin yüksek olduğu alanlar,

Yönetim yargılarına dayalı alanlara ilişkin önemli denetçi kararları (Yüksek oranda belirsizliklerin olduğu muhasebe tahminleri ve işletme yönetiminin yargılarını içeren mali tablolara ilişkin denetçi görüşleri),

- Denetlenen dönemde gerçekleşen önemli olay ve işlemlerin denetime olan etkileri.

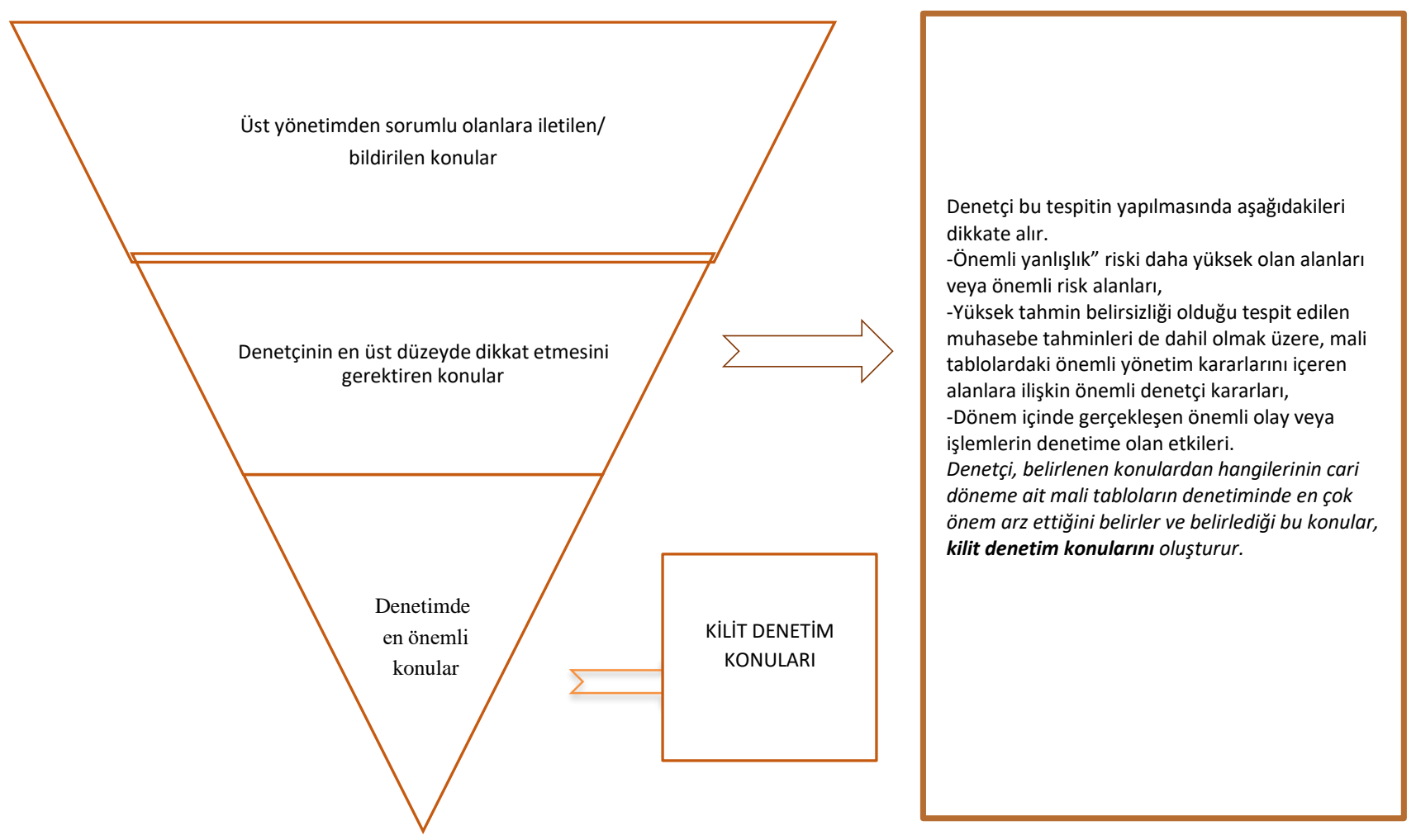

Şekil 1. Kilit denetim konularının tespitine ilişkin çerçeve (IFAC-IAASB, 2016)

UDS 701 denetçilere, hangi konuların kilit denetim konusu (key audit matters) olarak bildirilmesi gerektiğini belirlemede yardımcı olmak için, "yargıya dayalı bir karar verme çerçevesi" sunmaktadır. Bu nedenle standart, denetçinin, denetim raporunda, nasıl iletişim kuracağına ilişkin kararını ve bu iletişimin şekli ve içeriğini, nihai olarak kilit denetim konularını, daha fazla şeffafık sağlama gereği olarak bildirme amacı ile ele almaya yöneliktir.

Burada ifade edilen yargıya dayalı karar alma çerçevesi üç aşamada gösterilebilir (https://www.ifac.org/system/files/publications/files/2016-2017-IAASBHandbook-Volume-3.pdf).

1. Üst yönetimden sorumlu olanlara bildirilen konular: Kilit denetim konuları, denetçinin, denetim sırasında üst yönetimden sorumlu olanlara bildirdiği ve iletişim kurduğu konular arasından belirlenir. UDS 260 “Üst Yönetimden Sorumlu Olanlarla Kurulacak İletişim” standardı gereğince, denetçinin yapılan denetimden elde edilen önemli bulguları, üst yönetime bildirmesi şartı bulunmaktadır. Düzeltilmiş UDS 260 standardına göre, denetçi, üst yönetimden sorumlu olanlara belirlediği önemli riskler de dahil olmak üzere, denetimin planlanan kapsamını bildirir.

2. Denetimin gerçekleştirilmesinde, denetçinin azami düzeyde dikkat etmesini gerektiren önemli bir konu olabileceğine dair belirtiler şunlardır:

- Konu, denetçiye yeterli ve uygun denetim kanıtı elde etmede zorluklar getirmiştir, 
- Konu, denetçiye görüş oluşturmada zorluklar çıkarmıştır,

- Konu, mali tablolardaki karmaşıklık ve önemli yönetim kararları alanları ile ilgilidir.

Denetçinin, üst yönetimden sorumlu olanlara bildirilen konular arasından; denetimin yürütülmesi sırasında en üst düzeyde dikkat etmesini gerektiren konuları belirlerken, aşağıdaki hususları göz önünde bulundurması istenir (UDS 701; Akullo, 2019)

- UDS 315'e göre "önemli yanlışlı" riski daha yüksek olarak değerlendirilen veya önemli riskli olduğu belirlenen alanlar,

- Yüksek tahmin belirsizliğine sahip olduğu belirlenen, muhasebe tahminleri dahil yönetimin önemli yargılarını içeren mali tablo alanlarına ilişkin önemli denetçi yargıları,

- Dönem içinde gerçekleşen önemli olay veya işlemlerin denetime olan etkileri

Denetçi, belirlediği konulardan hangilerinin cari döneme ait mali tabloların denetiminde en önemli konuları belirler ve bunlardan kilit denetim konularını oluşturur.

3. Kilit denetim konularının belirlenmesinde son adım, denetimin yürütülmesinde en önemli olan konuları, cari dönem konuları arasından (2.) seçmektir. Bu bir mesleki yargı meselesidir ve işletmenin büyüklüğü ve karmaşıkığından, işin ve çevresinin şartlarından ve denetim sözleşmesinin gereklerinden ve koşullarından etkilenebilir (yani işletmeye özgü veya denetime özgü faktörler, denetçinin kararını etkilemektedir).

Üst yönetimden sorumlu olanlara bildirilen bir konunun öneminin ve bu konunun kilit denetim konusu olup olmadığının belirlenmesinde göz önünde bulundurulabilecek ve rehberlik sağlayabilecek etkenler ise şunlardır (Nancy Akullo, 2019):

Yönetimden sorumlu olanlar ile iletişimin niteliği ve kapsamı;

Hedef kullanıcıların bir bütün olarak mali tabloları anlaması bakımından konunun önemi ve özellikle mali tablolar açısından önemliliği,

Temel muhasebe politikasının niteliği veya sektördeki diğer işletmelere kıyasla yönetimin muhasebe politikası seçiminin karmaşıklığı ve öznelliği,

Konuyla ilgili hata veya hile kaynaklı düzeltilmiş ve biriktirilen düzeltilmemiş yanlışıkların nitelik veya nicelik bakımından önemliliği,

Denetim çabalarının niteliği ve kapsamı;

Denetim tekniklerinin uygulanmasındaki zorlukların niteliği ve ciddiyeti,

Konuyla ilgili tespit edilen kontrol eksikliklerinin niteliği ve önemliliği.

\section{Kilit denetim konularının bildirilmesi}

Denetçi raporunun yeni şekli (genişletilmiş), denetçilerin risk değerlendirmesi ve belirlenmiş denetim risklerinin azaltılmasına yönelik denetim yaklaşımının seçilmesi hakkında daha ayrıntılı bilgi vermektedir. Kilit denetim konularının bildirilmesiyle birlikte, denetim raporları; denetçilerin denetlenmiş mali tabloların doğru ve adil sunumunun gerekliliğini yerine getirmek için hangi iş ve işlemlerin yapıldığı ve denetimde en zor alanların neler olduğu ve gerekli denetim kanıtlarını nasıl topladıkları hakkında kullanıcılara bilgi vermektedir (Botez 2017). Denetçi raporunda kilit denetim bulgularının bildirilmesi, mali tablolara ilişkin açıklanan görüş çerçevesindedir. Denetim raporunda kilit denetim konusu ile ilgili olarak; kilit denetim konularının, denetçi görüşünden farklı bir görüş içermediğini, denetçinin yargısını oluştururken dikkate aldığı en önemli konular olduğunu belirten bir ifadenin yer alması gerekmektedir (UDS 701, 2017). Denetim raporunun kilit denetim konusu bölümünde ortaya konan, kilit denetim konularına ilişkin açıklamalar, mali tablolarda belirtilen açıklamalara (varsa) atıfta bulunur. Buna göre kilit denetim konuları bildirilirken, aşă̆ıdakilere yer verilmelidir (Akullo, 2019; UDS 701; Sayar \& Ergüden, 2016);

Bu konuya ilişkin hangi dipnotlarda açıklama yapııldı̆ıına dair atıfta bulunulmalıdır.

Bu konunun denetçi tarafından neden kilit denetim konusu olarak seçildiği açıklanmalıdır.

Bu konu ile ilgili uygulanan denetim prosedürlerine, konunun ele alınış biçimine yer verilmelidir

Yeni denetçi raporlarında içerik olarak; genel kurul, görüş, görüşün dayanağı, işletmenin sürekliliği ile ilgili önemli belirsizlikler (varsa), kilit denetim konuları, diğer bilgiler, yönetimin mali tablolara ilişkin sorumluluğu, bağımsız denetçinin sorumluluğu, mevzuattan kaynaklanan yükümlülüklere ilişkin rapor ve denetçi adresi ile birlikte tarih ve imza yer almaktadır. Yönetimin sorumluluğu ve denetçinin sorumluluğu ile ilgili metin içi ilaveler de ek olarak yeni denetim raporlarında yer almaktadır. Denetim raporlarında en önemli değişiklik, işletmenin sürekliliği ile ilgili önemli bir belirsizlik varsa ona yapılan vurgu ve kilit denetim konularının ayrı bir başlık altında sunumudur. Yapılan değişiklikler sonucunda, denetim raporları içerik olarak büyük ölçüde genişlemekle birlikte özellikle kilit denetim konularını içerecek şekilde uzun denetim raporları haline dönüştürülmüştür (Çağıdan\&Varıcı, 2019).

UDS 701; kilit denetim konularının, mali tabloların ilgili bölümlerine atıfta bulunmak üzere, denetim raporunun yararını artıran kısa bir açıklama yapmalarını gerektirir. Kilit denetim konuları, mali tabloların ve denetim süreçlerinin şeffaflı̆ını arttırmayı amaçlamakla birlikte, bu sürecin uygun bir şekilde yapıldığını da belgelemektedir (Honkomaki\&Oojala, 2019). Denetçi, denetim çalışması sonucunda belirlediği kilit denetim konularını "Kilit Denetim Konuları" ana başlığı altında alt bölümlere ayırarak raporlamaktadır. Kilit denetim konuları, denetçi raporunda "Görüşün Dayanağı" bölümünden sonra, "Kilit Denetim Konuları" başlığı altında sunulmalıdır. Denetim raporunda kilit denetim konusu olarak bildirilen konuların, varsa mali tablolarda yer alan açıklamalara atıfta bulunularak, neden kilit denetim konusu olarak belirlendiği, konunun denetimde nasıl ele alındığı sade ve anlaşııır biçimde açıklanmalıdır. Önemli olan başka bir konu da, raporda belirtilen kilit denetim konuları ve yapılan açıklamalar gizli bilgi içermemelidir /sır niteliğinde olmamalıdır (KGK, 2016, s.3-4).

Kilit denetim konularının belirlenmesi, sayısı, bunların bildirim sırası konularında herhangi bir sınırlandırma bulunmamaktadır. Bu bağlamda, bildirilen kilit denetim konuları denetçinin mesleki yargısına, tecrübe ve uzmanlığına, işletmenin ve işlem sayısının büyüklüğüne ve önemine göre değişiklik göstermektedir (KGK, 2016).

Denetçi, kilit denetim konularını raporunda ayrı bir bölümde açıklamaktadır. Bu bölümde kilit denetim konularının denetim sırasında en önemli konular olduğunu ve denetçi görüşü oluşturulurken dikkate alındığını ve denetçinin bu konular için ayrı bir görüş açıklamadığını belirtmektedir. Kilit denetim konuları, denetçinin mesleki muhakemesine göre, cari döneme ait mali tabloların denetiminde en çok önem arz eden konulardır. Bu konular, bir bütün olarak mali tablolara ilişkin yürütülen denetim çerçevesinde ve bu tablolara ilişkin görüş oluşturulurken ele alınmaktadır. Denetçinin raporunda şartlı veya olumsuz görüş belirtmesi ya da işletmenin sürekliliğine ilişkin ciddi belirsizliklerin bulunduğunu tespit etmesi durumunda, olumlu görüş dışında görüş belirtmesine neden olan konu veya işlemler nitelikleri itibariyle kilit denetim konularıdır. Fakat bu tür durumlarda kilit denetim konusu olarak bild irilmemektedir. Denetçi ilgili konuyu uygun denetim standartları çerçevesinde raporlamaktadır (UDS 701, UDS 705, UDS 570). Kilit denetim konularının denetim raporunda bildirilmesinin sağlayacă̆ı faydalar şu şekilde ifade edilebilir (UDS 701, m.4.).

Kilit denetim konularının bildirilmesinin hedefi, yürütülen denetime ilişkin daha fazla şeffaflık sağlayarak denetçi raporunun anlaşılabilirliğini ve iletişim değerini arttıracaktır.

Kilit denetim konularının bildirilmesi, denetçinin mesleki muhakemesine göre en çok önem arz eden konuların anlaşılmasında, mali tabloların hedeflenen kullanıcılarına karar almalarına yönelik ilâve bilgiler sağlayacaktır. Böylece, denetçi raporunun kapsamı genişleyeceğinden, kullanıcılara daha yararlı bilgi sağlayacaktır.

Kilit denetim konularının bildirilmesi, işletmenin ve yönetimin önemli muhakemelerde bulunduğu alanların anlaşılmasında hedef kullanıcılara yardımcı ve yol gösterici olacaktır.

Kilit denetim konularının denetçi raporunda bildirilmesi, hedef kullanıcıların işletmeyle, denetlenmiş tablolar veya yürütülen denetimle ilgili belirli hususlar hakkında yönetim ve üst yönetimden sorumlu olanlarla daha verimli düzeyde bir ilişki kurmalarına yardımcı olacaktır.

\section{Tartışma ve Sonuç}

Denetim kalitesi ülkelerin iktisadi faaliyetleri ve başarıları açısından büyük öneme sahiptir. Denetim kalitesi, denetim piyasasının temel bir dayanağıdır ve bilgi kullanıcılarının verilen görüşlere/güvenceye güvenmediği durumlarda denetimin bir değeri bulunmamaktadır (Cordos\&Fulop, 2015). Sonuç olarak, ulaşılan görüş ve denetçinin görüşe ulaşmak için kullandığı mekanizmalar önemli ve "kilit" niteliğindedir. Son yıllarda denetimin kalitesinin arttırılması ve özellikle 
denetim raporunun şeklinin değiştirilmesine ilişkin tartışmalar sonucunda öncelikle bağımsız denetimin, ihtiyaç duyulan bilgileri içermediğinden hareketle, denetim faaliyetine ilişkin iletişimin geliştirilmesi gerektiği ortaya çıkmıştır. Yapılan çalışmalar sonucunda yenilenmiş denetçi raporu ile ilgili olarak bazı standartlar yeniden gözden geçirilmiş ve önemli değişiklikler yapılmıştır.

Mali tablo kullanııılarının taleplerini karşılamaya yönelik olarak yürütülen çalışmalar neticesinde ortaya konan yenilenmiş denetim raporu biçimi ile birlikte yeni ve gözden geçirilmiş Uluslararası Denetim Standartları (UDS), IAASB tarafından 2016 yılı mali döneminden itibaren uygulanmak üzere yürürlüğe konmuştur. Söz konusu değişiklikler arasındaki önemli hususların başında "UDS 701 Kilit Denetim Konularının bildirilmesi” olmuştur. Bilgi kullanııılarının, denetim raporlarında, denetim süreciyle ilgili denetim raporlarında daha fazla bilgi talep etmeleri neticesinde, kilit denetim konuları kavramı gündeme gelmiştir. Kilit denetim konuları kavramı, denetim süresince en çok önem arz eden, denetçinin bu süreçte üzerinde daha çok çalıştığı ve zaman harcadığı denetim alanlarını ifade etmektedir.

UDS 701'e göre, bağımsız denetim raporunda denetçinin kilit denetim konularını bildirmesindeki temel amaç, hem denetim çalışmasına hem de işletmeye gerçekleştirilen denetimle ilgili olarak mevcut durum ve koşullarını bildirerek, bilgi kullanıııların ihtiyaçlarına uygun, yeterli ve daha açıklayıcı bilgi sağlamaktır. Aynı zamanda kilit denetim konularının bildirilmesi, bilgi kullanıcılarının işletmeyi ve denetlenen mali tablolardaki yönetim yargısı içeren önemli alanları anlamaları adına yardımcı olmaktadır. Bu standartla ve yenilenen denetim raporu şekliyle birlikte, gerçekleştirilen denetimle ilgili en önemli konuların "denetçi gözüyle" vurgulanması hedeflenmiştir.

Yeni denetçi raporlarıyla birlikte;

i. Denetimde şeffaflık artacaktır.

ii. Kullanıcılara gelişmiş iletişim aracılığı ile değer sunulacaktır.

iii. Kullanııılar, denetçiler ve yönetişimden sorumlu olanlar arasında, daha güçlü etkileşim kurulabilecektir.

iv. Kilit denetim konularının tanımlandığı alan ve konularla ilgili mesleki şüphecilik artacaktır.

Buna göre denetçi raporlarııı kapsamı genişledikçe, bilgi kullanıcılarına sunulacak bilginin de kalitesi artacak ve raporların iletişimsel değeri büyüyecektir. Özetle, denetim kalitesinin artmasıyla kullanıııların denetim kalitesi algısı da gelişecektir. Bu kapsamda gelecekteki çalışmalarda, kilit denetim konularının denetim kalitesine etkisi ve kalite algısı boyutunun araştırılması yararlı olacaktır.

\section{Kaynakça}

ACCA. (2018). Key audit matters: unlocking the secrets of the audit. https://www.accaglobal.com/content/dam/ACCA_Global/professional-insights/Key-auditmatters/pi-key-audit-matters.pdf

Accountancy Europe. (2019). Key audit matters In European banking sector. 7 October 2019. https://www.accountancyeurope.eu/publications/key-auditmatters-in-european-banking-sector/

AICPA. (2019). Codification of statements on auditing standards. May, 2019. Wiley.

Akullo, N. (2019). Implementation of audit reporting standards: Key audit matters, https://www.icpau.co.ug/news/implementation-auditor-reportingstandards-key-audit-matters

Asare, S. \& Wright, A. M. (2012). Investors', auditors', and lenders' understanding of the message conveyed by the standard audit report on the financial statements. Accounting Horizons, 26(2).

Bédard, J., Gonthier-Besacier, N., \& Schatt, A. (2018). Consequences of expanded audit reports: Evidence from the justifications of assessments in France. $A$ Journal of Practice \& TheoryAdvance online publication, 38(3), 23- 45.

Boolaky, P. K., \& Quick, R. (2016). Bank directors' perceptions of expanded auditor's reports. International Journal of Auditing, 20(2), $158-174$.

Botez, D. (2017). Updates regarding audit reporting. studies and scientific researches. Economics Edition. No 25.

Carcello, J. V. (2012). What do investors want from the standard audit report? results of a survey of investors conducted by the PCAOB's investor advisory group. The CPA Journal 82(1).

Cordoş, G.S. \& Fülöp, M.T. (2015). Understanding audit reporting changes: Introduction of key audit matters, Accounting and Management Information Systems, 14(1).

Çağıran, F. \& Varıcı, i. (2019). Bağımsız Denetim Standardı (BDS) 701 çerçevesinde kilit denetim konuları: Borsa İstanbul imalat sanayi sektöründeki işletmelerin denetim raporları üzerine bir analiz. International Journal of Economic and Administrative Studies, 22.

Doğan, A. (2018). Bağımsız denetimde yeni bir yaklaşım: kilit denetim konuları. Muhasebe Bilim Dünyası Dergisi, 20(1). 65-89.

Lennox, C. S., Schmidt, J. J., \& Thompson, A. (2019). Are expanded audit reports informative to investors? Evidence from the U.K. SSRN Electronic Journal. Working paper.

McGeachy, D. \& Arnold, C. (2017). Auditor reporting standards implementation: Key Audit Matters, https://www.ifac.org/knowledge-gateway/auditassurance/discussion/auditor-reporting-standards-implementation-key-audit

Goicoechea, E., Gómez-Bezares, F., \& Ugarte, J. V. (2019). Integrated reporting assurance: perceptions of auditors and users in Spain. Sustainability, $11(3)$, 713.

Gold, A. H., \& Heilmann, M. (2019). The consequences of disclosing Key Audit Matters (KAMs): A review of the academic literature. Maandblad voor accountancy en bedrijfseconomie, 93(1).

Gomez, D. \& Guillamon, A. (2003). The usefulness of the audit report in investment and financing decisions. Managerial Auditing Journal 18, no. 6/7.

Gökgöz, A. (2018). Kilit denetim konularının bağımsız denetçi raporunda bildirilmesi ve Borsa İstanbul'da işlem gören işletmeler üzerine bir araştırma. Journal of Accounting, Finance and Auditing Studies, 4(2), 92-105.

Gray, I. \& Manson, S. (2000) "The audit process. principles, practice and cases", 2nd edition, Thomson Learning, U.S

Honkomakı, T. \& Ojala, H. (2019). Reporting transparency of key audit matters in the investment property industry. https://www.wu.ac.at/fileadmin/wu/o/eufin2019/UPDATED_Reporting_transparency_of_key_audit_matters_in_the_investment_property_industr y.pdf

IAASB, (2011). Enhancing the value of auditor reporting: exploring options for change. New York, NY: International Federation of Accountants

IAASB. (2012) Invitation to comment: improving the auditor's report.

http://www.ifac.org/system/files/publications/files/Auditor_Reporting_Invitation_to_Comment-final_0.pdf

IAASB. (2015). The new auditor's report: greater transparency into the financial statement audit. www.ifac.org/system/files/uploads/IAASB/AuditorReporting-Fact-Sheet.pdf

IAASB, (2015), www.ifac.org/auditing-assurance/clarity-center

IAASB. (2016). Determining and communicating key audit matters, prepared by the auditor reporting implementation working group, https://www.iaasb.org/publications-resources/determining-and-communicating-key-audit-matters

IAASB (2017) International Standards on Auditing (ISAs).

Kavut, F.L. \& Güngör, N. (2018). Bağımsız denetimde kilit denetim konuları: BiST-100 şirketlerinin 2017 yılı analizi. Muhasebe Enstitüsü Dergisi. 16(59), 59-70.

KPMG. (2019). Key audit matters: Auditor's report snapshot. https://assets.kpmg/content/dam/kpmg/lk/pdf/key-audit-matters-aug-2019.pdf

Mock, T., Bedard, J., Coram, P. J., Davis, S. M., Espahbodi, R., \& Warne, R. C. (2013). The audit reporting model: current research synthesis and implications. Auditing: A Journal of Practice \& Theory, 32(1).

Nwaobia, A. N., Luke, O., \& Theophilus, A. A. (2016). The new auditors' reporting standards and the audit expectation gap. International Journal of Advanced Academic Research, 2(11).

Prasad, P. \& Chand, P. (2017). The changing face of the auditor's report: Implications for suppliers and users of financial statements. Australian Accounting Review 83(27).

PCAOB (2017). AS 3101: The auditor's report on an audit of financial statements when the auditor expressed an unqualified opinion. 
Celayir, D. \& Türedi, $H$.

Sakarya Üniversitesi İsletme Enstitüsü Dergisi, (2021): 203-208

Sayar, Z., \& Ergüden, E. (2016). Son düzenlemeler ve gelişmeler kapsamında değişecek ve yenilenecek bağımsız denetçi raporları. Muhasebe ve Denetime Bakış. 48.

Schuetze, P. W. (1994). A mountain or a molehill", Accounting Horizons. 8.

Segal, M. (2017). ISA 701: Key Audit Matters-An exploration of the rationale and possible unintended consequences in a South African. Journal of Economic and Financial Sciences, 10(2), 376-391.

Turner J. L., Mock T. J., Coram, P.J., \& Gray, G.L. (2010). Improving transparency and relevance of auditor communications with financial statement users. Current Issues in Auditing 4(1). www.ifac.org/system/files/publications/files/2016-2017-IAASB-Handbook-Volume-3.pdf

Uzay, Ş. \& Köylü, Ç. (2018). Kilit denetim konuları: Borsa İstanbul üzerine bir araştırma. Erciyes Üniversitesi Iktisadi ve Idari Bilimler Fakültesi Dergisi, 52. 4770.

Vanstraelen, A., Schelleman, C., Meuwissen, R. \& Hofmann, I. (2012). The audit reporting debate: Seemingly intractable problems and feaseble solutions. European Accounting Review. 21(2). 